Reprod. Nutr. Dévelop., 1987, 27 (1 A), 45-55.

\title{
Valorization of rapeseed meal. 2. Nutritive value of high or low-glucosinolate varieties and effect of dehulling
}

\author{
M. VERMOREL, J. J. BAUDET (*)
}

with the technical assistance of $Y$. ANGLARET, Simone GASNET, C. LEOTY, Marinett MEYER and $R$. SOUCHET

I.N.R.A., Laboratoire d'Etude du Métabolisme Energétique, Theix, 63122 Ceyrat, France.

(*) CETIOM, Centre Technique Interprofessionnel des Oléagineux Métropolitains, rue Monge, Parc Industriel, 33600 Pessac, France.

Summary. Five groups of 12 growing rats each were fed a control diet or one of 4 experimental diets composed of either high glucosinolate (Jet Neuf) or low glucosinolate (Tandem) rapeseed meal.

After a 3-day adaptation period, the rats were fed ad libitum for 15 days. Both meals were given dehulled or non-dehulled. The Tandem rapeseed meal provided all the protein and Jet Neuf half the protein of the corresponding diets.

Dehulling the seeds significantly increased the energy and protein digestibility of the rapeseed meals $(+16.5$ and +6.3 or 10.4 points, respectively), their digestible energy and digestible protein contents $(+28$ and $+30 \%)$ and metabolic utilization of digestible protein in the indirect nitrogen balance trial. Conversely, in the feeding trial, the feed efficiency of the dehulled meal diets was lower than that of the non-dehulled meal diets. However, dehulling the Tandem rape seeds did not seem to reduce lysine availability. Finally, feeding dehulled Tandem rapeseed meal as the sole protein source did not significantly increase the liver weight of the rats.

\section{Introduction.}

The new French rapeseed varieties such as Tandem and Darmor, known as double zero, have 3 to 5 times less glucosinolate than the first varieties without erucic acid, such as Jet Neuf ( 30 to 60 vs 150 to $180 \mathrm{mM} / \mathrm{kg}$ of meal), but they have the same production potential (Morice, 1983). They can replace two-thirds to three-quarters of the soya meal in feeds for fattening pigs without a reduction in animal performance (Bourdon and Baudet, 1984).

In addition, dehulling rape seeds before oil extraction eliminates most tannins, reduces by half the crude fibre content and, in pigs, improves the protein and digestible energy content by a mean of $17 \%$ and protein digestibility by $6 \%$. Thus, except for its lower lysine content, dehulled low-glucosinolate rapeseed meal provides a nutritive value similar to that of soya 48 (Bourdon, 1986). However, the technological conditions (temperature, pressure) of rapeseed meal detoxicification by roasting may modify its protein value (Josefsson, 1975; 
Slominski, Rakowska and Krymanski, 1983) and in particular reduce lysine availability (Sarwar, Shannon and Bowland, 1975). Finally, dehulled rapeseed meal appears more susceptible to heat than meal obtained from whole seed, reducing lysine content and its availability for pigs (Bourdon, Perez and Baudet, 1984).

The objective of the present experiment was to study the nutritive value of a normal rapeseed meal and of a low-glucosinolate meal in growing rats; both meals were prepared with and without dehulling.

\section{Material and methods.}

Rapeseed meal samples studied (table 1). - The two winter rapeseed varieties studied were grown in the Landes department in 1981-1982. Part of the seed was dehulled in the CETIOM experimental workshop on a chain using a CETIOM centrifugal dehuller and a HEF fluidized bit cleaner (Chone, 1983). The meals were prepared by the normal method : heating at $95-100{ }^{\circ} \mathrm{C}$ for 20 to 25 min under constant pressure, hexane extraction, desolventization by heating for $40 \mathrm{~min}$ to $60{ }^{\circ} \mathrm{C}$, then vapor injection and roasting for $6 \mathrm{~min}$ at $105^{\circ} \mathrm{C}$. The total glucosinolate, isothiocyanate (ITC) and vinyloxazolidene-2-thione (VTO) contents of the rapeseed meals were determined by the methods of Thies (1978) and Youngs and Wetter (1967), respectively. The characteristics of the rapeseed meals studied were the following :

JN : meal from the Jet Neuf variety, non-dehulled, relatively low glucosinolate content ;

JND : meal from Jet Neuf after dehulling. Dehulling reduced by $38 \%$ crude fibre, NDF and lignin contents, and resulted in a $22 \%$ increase in total glucosinolate, ITC and VTO contents, a $15 \%$ increase in total protein and lysine contents and in a $7 \%$ reduction in threonine content $(19 \%$ of its concentration in protein, i.e. 4.00 vs $4.94 \%$ ). In contrast, the available lysine content (acid orange 12 method)

TABLE 1

Chemical composition of the rapeseed meal samples (per kg dry matter).

\begin{tabular}{lcccr}
\hline & \multicolumn{2}{c}{ Jet Neuf } & \multicolumn{2}{c}{ Tandem } \\
\cline { 2 - 5 } Rapeseed samples & Normal & Dehulled & Normal & Dehulled \\
\hline Ash (g) & 75 & 82 & 77 & 81 \\
Crude protein (g) & 362 & 417 & 361 & 423 \\
Lysine (g) & 21.2 & 24.3 & 21.6 & 22.8 \\
Threonine (g) & 17.9 & 16.7 & 15.9 & 19.0 \\
Crude fibre (g) & 119 & 74 & 134 & 78 \\
ADF (g) & 215 & 122 & 230 & 136 \\
NDF (g) & 290 & 183 & 304 & 80 \\
Lignin (g) & 103 & 67 & 120 & 4676 \\
Gross energy (Mcal) & 4731 & 4659 & 402 & 42 \\
Glucosinolates (mM) & 123 & 150 & 41 & 12 \\
ITC (mM) & 34 & 40 & 11 & 28 \\
VTO (mM) & 71 & 88 & 26 & \\
\hline
\end{tabular}


was reduced $(17.4$ vs $18.0 \mathrm{~g} / \mathrm{kg}$ DM) as was lysine availability (72 vs $85 \%)$ (Chone, 1983) ;

$\mathrm{T}$ : non-dehulled meal from the Tandem variety; total glucosinolate, ITC and VTO contents : about one-third of those in Jet Neuf meal. Crude fibre and lysine contents were $13 \%$ higher but ADF and NDF contents were only $6 \%$ higher. Total protein and lysine contents were similar to those of Jet Neuf meal ;

TD : rapeseed meal from the Tandem variety after dehulling. Dehulling reduced crude fibre and ADF contents by $42 \%$ and lignin by $26 \%$ but did not change markedly total glucosinolate, ITC and VTO contents. In contrast, it improved the total protein and threonine contents by $17 \%$, but lysine content by only $5 \%$. As a result, the relative percentage of lysine in protein was reduced by $10 \%(5.4 \mathrm{vs}$ 6.0). The lower content of available lysine (acid orange 12 method) $(17.2 \mathrm{vs}$ $19.6 \mathrm{~g} / \mathrm{kg} \mathrm{DM}$ ) indicated a marked reduction in its availability (75 vs $90 \%$ ) (Chone, 1983).

TABLE 2

Composition of the diets $(\mathrm{g}$ per $\mathrm{kg}$ dry matter).

\begin{tabular}{|c|c|c|c|c|c|}
\hline \multirow{2}{*}{ Diets } & \multirow{2}{*}{ Control } & \multicolumn{2}{|c|}{ Jet Neuf } & \multicolumn{2}{|c|}{ Tandem } \\
\hline & & Normal & Dehulled & Normal & Dehulled \\
\hline Rapeseed cake & - & 172 & 148.6 & 377 & 307.5 \\
\hline Herring meal & 150 & 78 & 78 & - & - \\
\hline DL-Méthionine & 2.5 & 2.0 & 2.0 & - & - \\
\hline L-Lysine & - & 0.5 & 0.5 & 0.5 & 0.5 \\
\hline Wheat starch & 769.5 & 679.5 & 702.9 & 554.5 & 624 \\
\hline Vitamin mixture & 18 & 18 & 18 & 18 & 18 \\
\hline Maize oil & 20 & 20 & 20 & 20 & 20 \\
\hline Minerals & 40 & 30 & 30 & 30 & 30 \\
\hline \multicolumn{6}{|l|}{ Chemical composition } \\
\hline Crude protein & 122 & 128 & 126 & 134 & 130 \\
\hline Lysine & 10.0 & 9.4 & 9.4 & 8.6 & 7.5 \\
\hline Threonine & 5.2 & 5.9 & 5.2 & 6.0 & 5.8 \\
\hline Crude fibre & - & 20.5 & 11.0 & 50.5 & 24.0 \\
\hline Glucosinolates (mM) & - & 21.2 & 22.3 & 15.5 & 12.9 \\
\hline ITC (mM) & - & 5.8 & 5.9 & 4.2 & 3.7 \\
\hline VTO $(\mathrm{mM})$ & - & 12.8 & 13.1 & 9.9 & 8.6 \\
\hline
\end{tabular}

Composition of the 5 diets studied (table 2). - The amounts of rapeseed meal in the 4 experimental diets varied with differences in their glucosinolate contents. As a matter of fact, to obtain satisfactory rat growth, the glucosinolates fed were limited to $22 \mathrm{mM} / \mathrm{kg}$ of feed (Vermorel, Fayet and Baudet, 1978). The Tandem rapeseed meal was the sole protein source of the T and TD diets. In contrast, the Jet Neuf meal provided only half the protein of the JN and JND diets, the rest being in the form of herring meal. The protein level was fixed at a minimum and the diets were supplemented with lysine to meet the essential amino acid require- 
ments of growing rats (Vermorel, 1972). The diets, all complemented with minerals, vitamins and essential fatty acids, were :

- control diet (C : composed of herring meal supplemented with methionine and wheat starch ;

- JN diet : protein content slightly higher than that of the control, considering its lower digestibility ;

- JND diet : protein, lysine and glucosinolate contents similar to those of the JN diet but the crude fibre content only half. Threonine supply was $12 \%$ lower than for the other rapeseed diets :

- T diet : lysine content lower than those of the 3 preceeding diets ; glucosinolate level $30 \%$ lower than in JN and JND diets but the crude fibre content much higher $(5.0$ vs 2.0 and $1.1 \%$, respectively) ;

- TD diet : Iysine supply much lower than in the other diets $(7.5$ vs 8.6 or $9.4 \mathrm{~g} / \mathrm{kg} \mathrm{DM})$; glucosinolate and crude fibre contents lower than those of the non-dehulled T diet (2.4 vs $5.0 \%)$.

Animals. - Sixty male Sprague-Dawley rats of average weight $(54 \mathrm{~g})$ were randomly allotted to 5 groups of 12 animals each.

Feeding. - Over a period of 18 days, the rats received ad libitum one of the 5 diets in the form of wet mash. To facilitate rat adaptation, the experimental diets were mixed with the control diet and fed in increasing proportions $11 / 4 ; 1 / 2$; $3 / 4)$ for the first 3 days, and then pure. The quantities of dry feed distributed, refused and ingested were determined every day.

Weighing. - The rats were weighed on the first day of the experiment, then twice a week, and on the penultimate and last days of experimentation.

Diet and rapeseed meal digestibility measurements. - The faeces and urine of 6 rats from each group were collected separately over a period of 7 days ; the faeces were freeze-dried. Rapeseed meal digestibility was calculated from that of the corresponding diet using values for starch and maize oil (98\%) and herring meal protein $(91.5 \%)$ obtained with the control diet.

Sampling at sacrifice. - The rats were sacrificed with ether in the morning at fast. The liver was removed and weighed. The gut contents were eliminated. Animal weight wàs measured again in order to calculate empty body weight gain.

Statistical analysis. - One or two-way analysis of variance and Student's t-test were used (Snedecor and Cochran, 1968).

\section{Results.}

Diet appetibility (table 4). - In the case of the JN and JND diets, in which dehulled or normal meal from Jet Neuf provided only half the protein, the average dry matter intake after 3 days of adaptation was 36 and $43 \%$ lower, respectively, 


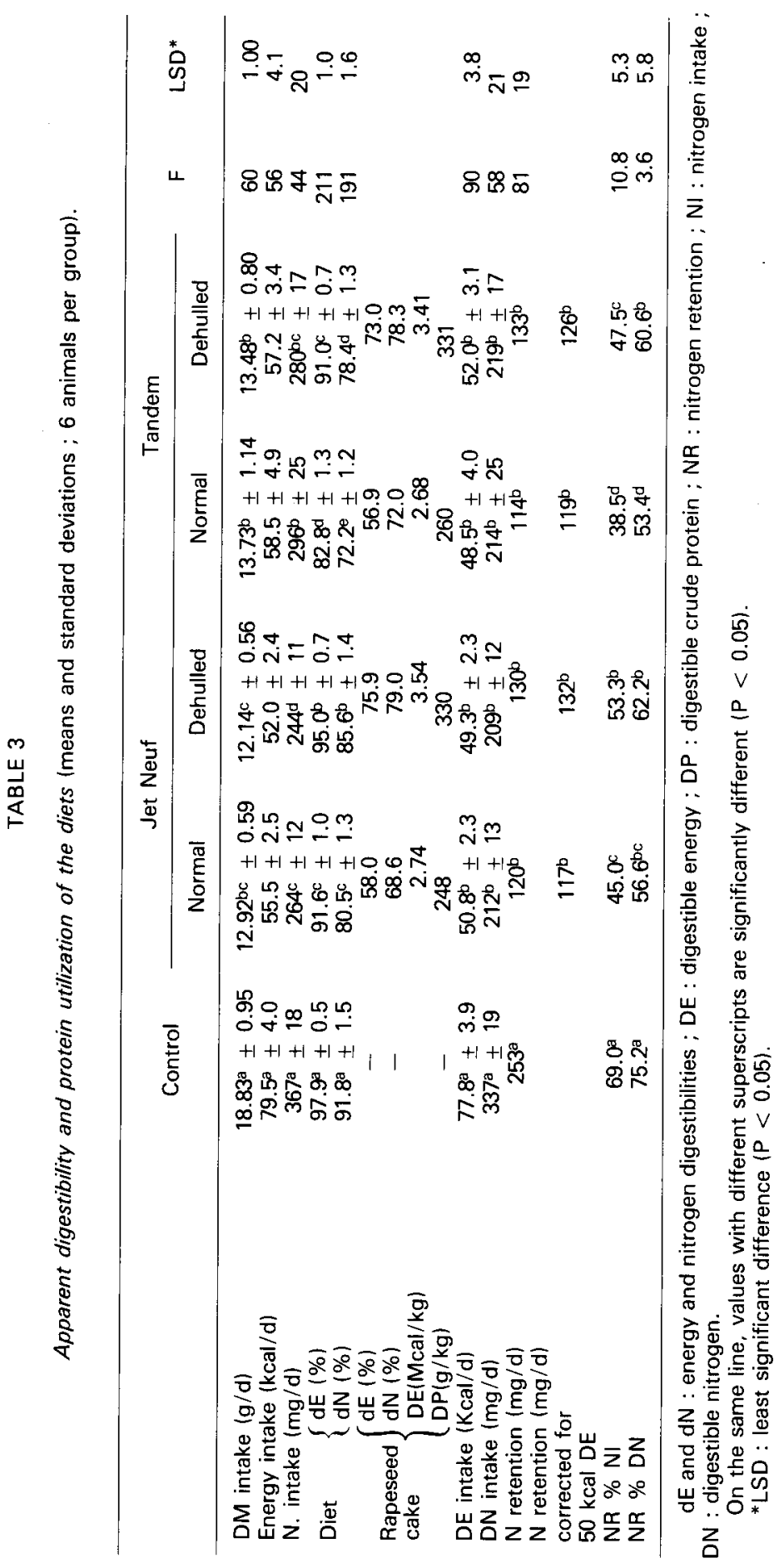


than with the control diet $(P<0.001)$. In contrast, for the $T$ and TD diets, in which normal or dehulled Tandem meal provided all the dietary protein, dry matter intakes were $30 \%$ lower than with the control diet, but 10 and $19 \%$ higher than for JN and JND, respectively $(P<0.001)$.

Digestive utilization of diets and rapeseed meal (table 3). - The energy and protein digestibilities of the diets based on rapeseed meal were significantly lower ( $P<0.001$ ) than those of the control diet. However, dehulling the meal significantly improved digestive utilization of the corresponding diets $(P<0.001)$.

The energy digestibilities and digestible energy contents of Jet Neuf and Tandem meals were similar. In contrast, apparent protein digestibility of Tandem meal was 3-4 points $(5 \%)$ higher than that of Jet Neuf. Dehulling the rapeseed gave an average increase of 16.5 points $(29 \%)$ in energy digestibility and of 10.4 and 6.3 points in protein digestibility $(15$ and $9 \%)$ for Jet Neuf and Tandem meals, respectively. As a result, the digestible energy and digestible protein contents of dehulled meals were improved by 28 and $30 \%$, respectively.

Metabolic utilization of dietary protein (table 3). - Due to the large difference in food intake, the metabolic utilization of protein in the diets containing rapeseed meal could not be easily compared with that of the control diet during the digestibility period. However, the intakes of digestible energy and protein by rats receiving the rapeseed diets were quite similar. Earlier studies on growing rats showed that, for comparable growth rates, an increase of $1 \mathrm{kcal}$ in DE intake was accompanied by an increase of $3.5 \pm 0.8 \mathrm{mg}$ in nitrogen retention. The quantity of protein retained by the rats receiving rapeseed meal could thus be corrected for a given DE intake $(50 \mathrm{kcal} /$ day $)$. The results showed that the corrected protein retention among the 4 groups fed rapeseed did not differ significantly. However, a 2-way analysis of variance showed that dehulling improved protein retention in the groups fed Jet Neuf meal $(P<0.05)$.

Net protein utilization (NPU $=100 \times$ protein gain/protein intake) of the $\mathrm{JN}$ and JND diets, in which the normal or dehulled meal from Jet Neuf provided only half the protein, was higher than with the Tandem diets, where all the protein came from the meal $(P<0.01)$. In addition, dehulling significantly improved the NPU of the Jet Neuf and Tandem diets $(P<0.001)$. These differences may be explained in part by an increase in protein digestibility, but dehulling did appear to improve the metabolic utilization of protein, as the coefficient of protein retention $(C R=100 \times$ protein gain/digestible protein) was increased by a mean of 6.4 points $(P<0.01)$. Finally, it should be noted that, on an average, the metabolic utilization of protein of Tandem rapeseed meal was similar to that of the mixture of Jet Neuf meal and herring protein : the CR (59.4 and 57.0, respectively) were not significantly different and the same was true of the mean protein gain for a given DE intake.

Rat growth rate and feed efficiency (table 4). - After the three days of dietary adaptation, the live weight gain of the rats fed rapeseed meal was on an average $45 \%$ lower than that of the control group and the average weight of gut 


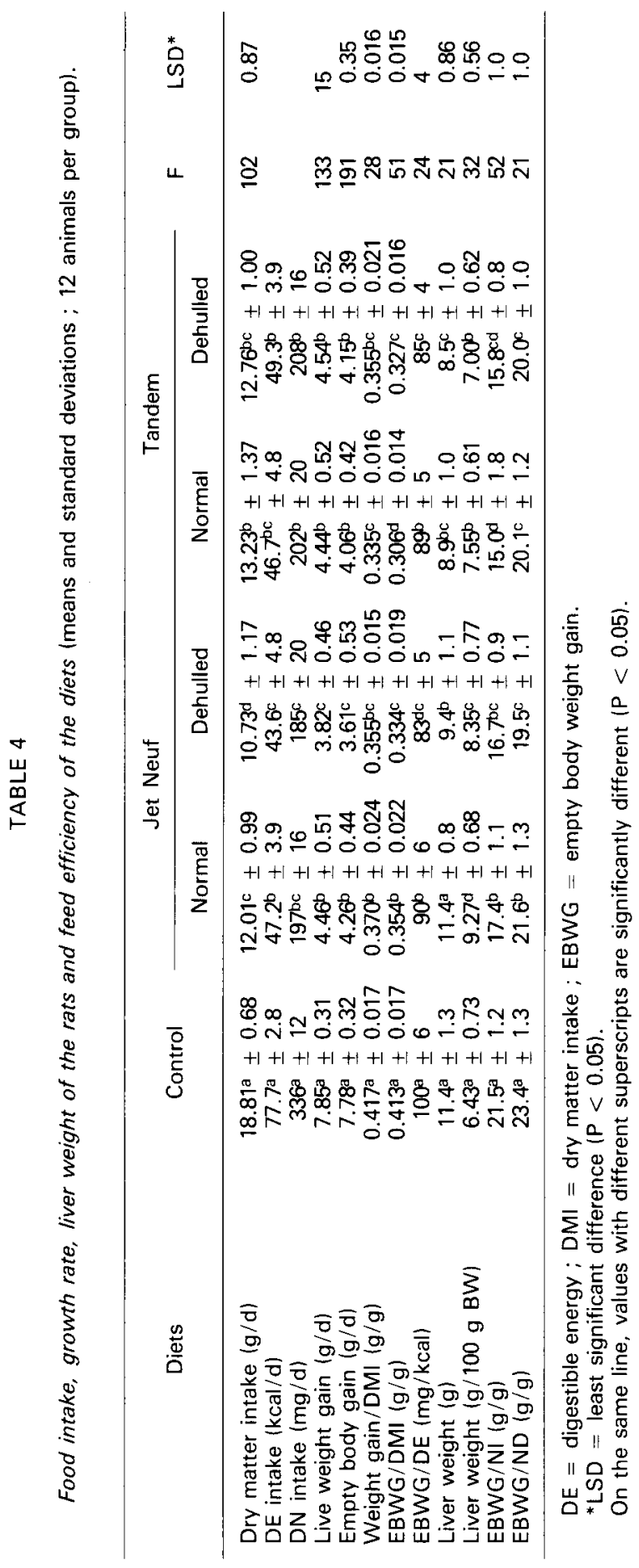


content was twice as high $(7.3$ vs $3.7 \%$ of live weight). This empty body weight gain (EBWG) of the rats receiving rapeseed was only half that of the control animals $(4.0$ vs $7.8 \mathrm{~g} /$ day). Further, the gain of the JND group, where food intake was lowest, was significantly less (by $13 \%$ ) than that of the other three groups receiving rapeseed. Moreover, the feed efficiency (expressed as $\mathrm{mg}$ EBWG/kcal $\mathrm{DE}$ ) of the dehulled rapeseed diets (JD and TD) was significantly less (average of $6.5 \%)$ than that of the diets containing non-dehulled meal (JN and T).

The protein efficiency ratio (PER $=E B W G /$ protein intake) was lower with the rapeseed diets than with the control diet and $10 \%$ lower with the Tandem diets (providing all the protein from the rapeseed) compared with those prepared from Jet Neuf, which provided only half the total protein. The empty body weight gain per $\mathrm{g}$ of digestible protein is a useful criterion of metabolic utilization of protein. A 2-factor analysis of variance showed that there was no significant difference between the Tandem and Jet Neuf diets and that dehulling rapeseed, which improved protein digestibility, generally had no significant effect on the metabolic utilization of the protein.

Rat liver weight (table 4). - Expressed per $100 \mathrm{~g}$ of empty body weight, the liver weight in rats receiving rapeseed meal was significantly higher thant that in control animals. However, the difference was only $9 \%(P<0.05)$ with the diet of dehulled Tandem meal which provided all dietary protein, whereas it was $30 \%$ with dehulled Jet Neuf meal and $44 \%$ with normal Jet Neuf which provided only half the dietary protein.

\section{Discussion and conclusions.}

The proportions of ITC and VTO in comparison with total glucosinolates were the same in Tandem and Jet neuf meals, with or without dehulling, although the proportion of ITC is generally higher with the Tandem rapeseed variety (Bourdon, 1986). Dehulling the Tandem rapeseed did not markedly increase its total glucosinolate, ITC and VTO contents, although the glucosinolate content is lower in hulls than in kernels (Bayley and Hill, 1975 ; Bell and Shires, 1982). The $19 \%$ reduction in threonine content of the dehulled meal from Jet Neuf, for which there was no evident explanation, was not found with Tandem meal. In reverse, dehulling the rapeseed did not alter the lysine content of protein in Jet Neuf meal, whereas there was a $10 \%$ drop with Tandem meal, as reported by Bourdon, Perez and Baudet (1984).

The higher food intake with the Tandem rapeseed (only protein source) compared with that of Jet Neuf (only half of dietary proteins provided) may be due to the different glucosinolate contents of the diets (Vermorel, Davicco and Evrard, 1987). Similarly, the $50 \%$ reduction in the weight of the gut contents of rats fed dehulled rapeseed meal agrees with earlier results (Vermorel, Fayet and Baudet, 1978), and may be explained by reduced fermentation in the caecum and large intestine.

The energy digestibilities of Jet neuf and Tandem meals were similar, in spite of the $10 \%$ higher crude fibre and ADF contents in the latter. In contrast, the 
energy digestibility of Tandem meal in pigs was 4 points above that of Jet Neuf (Bourdon, 1986). The results on protein agree with those obtained on pigs (Bourdon, 1986) : 3.5 point higher digestibility (5\%) for Tandem than for Jet Neuf.

In this trial, dehulling rape seeds had less effect than usual : the crude fibre contents of the meals were 7.4 and $7.8 \%$ versus the 6.6 . $\pm 0.5 \%$ reported by Bourdon (1986). In contrast, oil extraction appears to have been complete since the gross energy contents of the meals were very similar. The 17-point improvement $(30 \%)$ in energy digestibility and 6 to 10 -point (9 to $15 \%)$ improvement in protein digestibility agree with results obtained on rats (Vermorel, Fayet and Baudet, 1978) and on pigs (Bourdon, 1986).

The nitrogen balances and protein efficiency ratios (empty body weight gain per $\mathrm{g}$ of digestible protein) indicate that the metabolic utilization of protein was as good for Tandem meal (providing all the protein) as for the Jet Neuf and herring meal mixture. However, the results of dehulling were contradictory. In the nitrogen balances, dehulling increased significantly (an average of $10 \%$ ) the coefficient of protein retention and the quantity of protein gained $(9 \%)$ for a given digestible energy intake, but this result was obtained on groups of 6 rats only. In the feeding trial, dehulling had no significant effect on empty body weight gain per $\mathrm{g}$ of digestible protein, but it significantly reduced empty live weight gain per kcal of digestible energy. The lower performances obtained with the diet containing dehulled Jet Neuf cannot be explained by a threonine deficit, for the requirement of growing rats was met, even taking into account the poor ileal digestibility of rapeseed threonine in pigs (Sauer et al., 1982). In contrast, the performances of rats fed dehulled Tandem meal were not reduced in spite of the theoretical lysine deficit of the diet $(7.2 \mathrm{vs} 8.5 \mathrm{~g} / \mathrm{kg})$, taking into account the ileal digestibility of rapeseed lysine reported in pigs by Sauer et al. (1982). However, higher food intake and live weight gain could be expected due to the lower crude fibre and glucosinolate contents of the diet; also, empty body weight gain per kcal of DE was significantly lower than with the Tandem meal.

Finally, the very small increase in liver weight of rats receiving dehulled Tandem meal should be noted. This may be due both to the very low dietary content of glucosinolates (Oliver, McDonald and Opozynska, 1971) and to elimination during dehulling of most of the tannins, which seem to be responsible for liver enlargement (Just, Hansen and Jensen, 1982).

In conclusion, although dehulling reduces the lysine content of Tandem rapeseed meal, and probably its availability, this rapeseed meal is a very good source of protein for growing rats and pigs, as shown by Bourdon (1986). Its possible concentration in diets depends mainly on its glucosinolate content which still varies greatly according to crop production conditions. 
Acknowledgements. - The authors wish to thank M. Larbier (I.N.R.A., Station de Recherches Avicoles) and D. Bourdon (I.N.R.A., Station de Recherches Porcines) for providing the amino acid and cell wall carbohydrate contents of the meals and $M$. Burghart (CETIOM) for preparing the experimental rapeseed meals. This study was a part of the CETIOM/I.N.R.A. 1983 programme of research on oil crops.

Résumé. Valorisation du tourteau de colza. 2. Valeur nutritive des variétés à faible ou forte teneur en glucosinolates et effet du dépelliculage.

Cinq lots de 12 rats en croissance ont reçu ad libitum pendant 18 jours 1 régime témoin ou 4 régimes composés de tourteau de colza à forte teneur (Jet Neuf) ou à faible teneur en glucosinolates (Tandem), tous deux dépelliculés ou non. Le tourteau Tandem fournissait la totalité des protéines du régime et le tourteau Jet Neuf seulement la moitié.

Le dépelliculage des graines de colza améliore de 16,5 et de 6,3 ou 10,4 points les digestibilités de l'énergie et de l'azote et de 28 et $30 \%$ les teneurs en énergie digestible et en matières azotées digestibles des tourteaux. L'utilisation métabolique des protéines du tourteau de colza Tandem ne semble pas réduite par le dépelliculage des graines d'après les résultats du bilan azoté et de l'essai d'alimentation. Enfin, le poids du foie des rats recevant le tourteau de colza Tandem dépelliculé, comme seule source de protéines, n'est pas significativement supérieur à celui des animaux témoins.

\section{Références}

BAYLEY H. S., HILL D. C., 1975. Nutritional evaluation of low and high fibre fractions of rapeseed meal using chickens and pigs. Can. J. anim. Sci, 55, 223-232.

BELL J. M., SHIRES A., 1982. Composition and digestibility by pigs of hulls fractions from rapeseed cultivars with yellow or brown seed coats. Can J. anim. Sci., 62, 557-565.

BOURDON D., 1986. Valeur nutritive des nouveaux tourteaux et graines entières de colza à basse teneur en glucosinolates pour le Porc à l'engrais. Journ. Rech. Porcine en France, 18, $13-28$

BOURDON D., BAUDET J. J., 1983. Valeur nutritive et possibilités d'utilisation du tourteau de colza dépelliculé pour le Porc à l'engrais. Proc. 6th int. Rapeseed Conf., Paris, 1524-1529.

BOURDON D., PEREZ J. M., BAUDET J. J., 1984. Nutritive value and utilization by the growing finishing pig of new types of rapeseed oil meals with low-glucosinolate content. In M. SORENSEN, Advances in the production and utilization of cruciferous crops (A seminar in the CEC programm of research on plant protein improvement Copenhagen, Denmark, Sept. 1984), World crops : production, utilization, description, vol. 11, 177-198. Martinus Nijhoff, Dr. W. Junk Publ., Dordreecht, the Netherlands.

CHONE E., 1983. Qualité des produits de transformation du colza double-zéro. C.-R. Acad. Agric. France, 69, 17-29.

JOSEFSSON E., 1985. Effects of variation of heat treatment conditions on the nutritional value of low-glucosinolate rapeseed meal. J. Sci. Fd. Agric., 26, 157-164.

JUST A., HANSEN V., JANSEN A., 1982. Quoted by RUNDGREN M., 1983.

MORICE J., 1983. Un nouveau colza : le colza double-zéro. C.-R. Acad. Agric. France, 69, 7-16.

OLIVER S. L., MCDONALD B. E., OPUZYNSKA T., 1971. Weight gain, protein utilization and liver histochemistry of rats fed low-and high-thioglucoside-content rapeseed meals. J. Physiol. Pharmacol., 49, 448-456.

RUNDGREN M., 1983. Low-glucosinolate rapeseed products for pigs. Anim. Feed Sci. Technol., 9, 239-262.

SARWAR G., SHANNON D. W. F., BOWLAND J. P., 1975. Effects of processing conditions on the availability of amino acids in soybean and rapeseed proteins when fed to rats. J. int. can. Sci. Technol. Aliment., 8, 137-141. 
SAUER W. C., CICHON R., MISIR R., 1982. Amino acid availability and protein quality of canola and rapeseed meal for pigs and rats. J. anim. Sci. 54, 292-301.

SLOMINSKI B. A., RAKOWSKA M., KRYMANSKI, 1983. The nutritive value of low-glucosinolate rapeseed meal processed at different heat-moisture conditions. Proc. 6th int. Rapeseed Conf., Paris, 1456-1459.

SNEDECOR G. W., COCHRAN, W. G., 1968. Statistical methods, 6th ed. The lowa Univ. Press, Ames, lowa, USA.

THIES W., 1978. Quantitative analysis of glucosinolates after their enzymatic desulfatation on ion exchange columns, 136-139. 5th int. Rapeseed Conf. Malmo, 12-16 june.

VERMOREL M., 1972. Besoins énergétiques et azotés du Rat en croissance. Expériment. anim., 5. 249-266

VERMOREL M., DAVICCO M. J., EVRARD J., 1987. Valorization of rapeseed meal. 3. Effects of glucosinolate content on food intake, weight gain, liver weight and plasma thyroïd hormone levels in growing rats. Reprod. Nutr. Dévelop., 27, 57-66.

VERMOREL M., FAYET J., BAUDET J. J., 1978. Valorisation du tourteau de colza. 1. Influence de l'élimination des glucosinolates, du dépelliculage et de l'extraction des alpha galactosides sur sa valeur nutritive. Etude sur le Rat en croissance. Ann. Biol. anim. Bioch. Biophys., 18, 1393-1412.

YOUNGS C. G., WETTER L. R., 1967. Microdetermination of the major individual isothio cyanates and oxazolidinethione in rapeseed. J. amer. Oil Chem. Soc., 44, 551-554. 